France-Lanord, C., Spiess, V., Klaus, A., Schwenk, T., and the Expedition 354 Scientists

Proceedings of the International Ocean Discovery Program Volume 354

publications.iodp.org

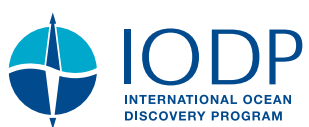

\title{
Contents
}

\section{Data report: paleomagnetic directions from IODP Expedition 354, Hole U1451 A, Cores 23H and 24H ${ }^{1}$}

Brendan T. Reilly, ${ }^{2}$ Joseph S. Stoner, ${ }^{2}$ Peter A. Selkin, ${ }^{3}$ Jairo F. Savian, ${ }^{4}$ and Laure Meynadier ${ }^{5}$

Keywords: International Ocean Discovery Program, IODP, JOIDES Resolution, Expedition 354, Site U1451, Hole U1451A, paleomagnetism, Bengal Fan, Pliocene/Pleistocene boundary, Gauss/Matuyama boundary

\author{
1 Abstract \\ 1 Introduction \\ 2 Methods \\ 4 Results \\ 6 Acknowledgments \\ 6 References
}

\begin{abstract}
International Ocean Discovery Program (IODP) Expedition 354 Site U1451 was drilled as the easternmost of seven sites forming a transect across the Bengal Fan at $8^{\circ} \mathrm{N}$. Site U1451 recovered the oldest Bengal Fan sediments of the expedition, providing a long sedimentary record and valuable chronostratigraphic constraints on seismic imaging. Two cores recovered from Hole U1451A, Cores $23 \mathrm{H}$ and $24 \mathrm{H}$, had uninterpretable archive-half remanent magnetizations measured on ship, despite having a calcareous clay lithology that was generally suitable for magnetostratigraphy in middle Pleistocene sediments. Shipboard biostratigraphy places these cores around the Pliocene/Pleistocene boundary. Paleomagnetic measurements of discrete subsamples, reported here, indicate that both Cores $23 \mathrm{H}$ and $24 \mathrm{H}$ contain no magnetic reversals, implying each core was deposited during a single polarity chron. These results suggest, based on sedimentation rate estimates, that the GaussMatuyama reversal and the Pliocene/Pleistocene boundary in Hole U1451A is located between the base of Core $23 \mathrm{H}$ and top of Core 24H (129.54-131.33 m CSF-A), although this needs to be confirmed by postexpedition biostratigraphic studies.
\end{abstract}

\section{Introduction}

International Ocean Discovery Program (IODP) Expedition 354 cored seven sites along a $\sim 320 \mathrm{~km}$ transect of the Bengal Fan at $8^{\circ} \mathrm{N}$ to investigate fan development and depocenter migration (Figure F1) (see the Expedition 354 summary chapter [France-Lanord et al., 2016b]). Because any one site includes local variations in depositional processes, the transect approach and accurate stratigraphic correlation of sites are essential for understanding sediment fluxes and the climate and tectonic history of the region. Although all sites recovered at least middle to late Pleistocene sediments, three sites were drilled deeper than $800 \mathrm{~m}$ drilling depth below seafloor, Method A (CSF-A), to investigate the Neogene and older Bengal Fan and/or pre-Bengal Fan deposits. The easternmost site, U1451, drilled on the western flank of the Ninetyeast Ridge, recovered the longest continuous record of Bengal Fan sedimentation, stretching back to at least the Oligocene (see the Site U1451 chapter [FranceLanord et al., 2016c]).

Pliocene and Pleistocene sediments recovered during Expedition 354 can broadly be categorized as high-accumulation rate sands and turbidites deposited by downslope processes and lower accumulation rate hemipelagic calcareous clays deposited when fan processes move the depocenter away from the site (see the Expedition 354 summary chapter [France-Lanord et al., 2016b]). The hemipelagic units proved useful for shipboard stratigraphy because they often contained abundant biomarkers, magnetic reversals, and tephra layers, and these hemipelagic sediments could often be identified as continuous reflectors in the seismic lines. One hemipelagic unit, deposited at $\sim 1-2 \mathrm{~cm} / \mathrm{ky}$ in the middle Pleistocene and recording the Matuyama/Brunhes boundary, Jaramillo Subchron, and/or Cobb Mountain Subchron, was observed at all sites across the transect, providing a framework for correlation between corederived chronologies and seismic imaging for the last $1.25 \mathrm{My}$ (see the Expedition 354 summary chapter [France-Lanord et al., 2016b]). The physical properties of these middle and late Pleistocene calcareous sediments, particularly magnetic susceptibility and sediment lightness $\left(\mathrm{L}^{*}\right)$, could be correlated between all seven sites where magnetostratigraphy or tephra layers provide initial tie

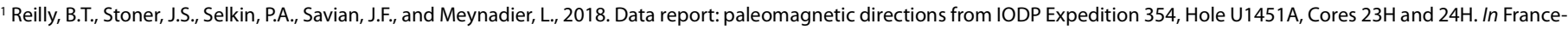
Lanord, C., Spiess, V., Klaus, A., Schwenk, T., and the Expedition 354 Scientists, Bengal Fan. Proceedings of the International Ocean Discovery Program, 354 : College Station, TX (International Ocean Discovery Program). https://doi.org/10.14379/iodp.proc.354.201.2018

${ }^{2}$ College of Earth, Ocean, and Atmospheric Sciences, Oregon State University, USA. Correspondence author: breilly@coas.oregonstate.edu

${ }^{3}$ School of Interdisciplinary Arts and Sciences, University of Washington, USA.

${ }^{4}$ Instituto de Geociências, Universidade Federal do Rio Grande do Sul, Brazil.

${ }^{5}$ Institut de Physique du Globe de Paris-Sorbonne Paris Cité, Université Paris Diderot, France.

MS 354-201: Received 28 February 2018 • Accepted 1 June 2018 • Published 7 August 2018

This work is distributed under the Creative Commons Attribution 4.0 International (CC BY 4.0) license. (cc) BY
} 
Figure F1. Locations of IODP Expedition 353 Site U1444 (Clemens et al., 2016) and Expedition 354 transect Sites U1449-U1455 (France-Lanord et al., 2016b). Green circle $=$ Site U1451. Modified after France-Lanord et al. (2016a).

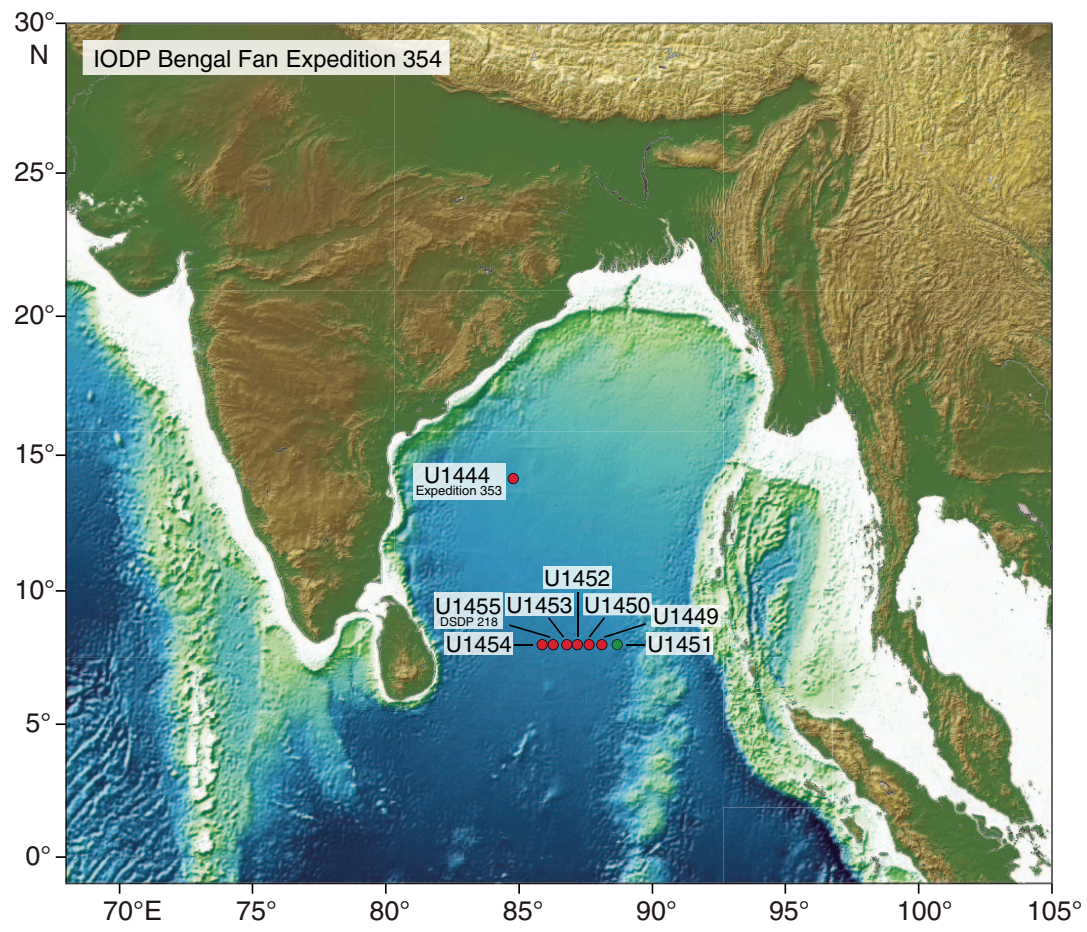

points, suggesting the signals in this facies are driven by regional (transect wide) processes and not their proximity to the active channel-levee system.

Identifying magnetostratigraphic constraints beyond the middle Pleistocene was challenging during Expedition 354. The near-equatorial location of each site and pervasive vertical drill string overprint made inclination difficult to use in determining polarity. For the most part, sediments were recovered in a single hole at each site, meaning that as much as meters of sediment were not recovered between cores and there was no overlap to compare declination. Relative changes in declination within a single core, where all sections were split along the same plane, were useful to identify reversals. Many, but not all, cores recovered using the advanced piston corer (APC) system could be oriented using the Icefield MI-5 or FlexIT core orientation tools. However, the successful recovery of sandy, heterogeneous, and poorly consolidated fan sediments relied heavily on the half-length APC (HLAPC), which could not be oriented and recovered short $(<4.5 \mathrm{~m})$ relative declination intervals.

Early Pleistocene and Pliocene hemipelagic sediments were recovered at Site U1451; however, magnetostratigraphic interpretations were often ambiguous or uninterpretable due to difficulties discussed earlier and scattered paleomagnetic directions. Of particular interest were the calcareous clay sediments recovered in APC Cores 354-U1451A-23H and 24H (121.50-138.14 m CSF-A), which were not oriented using either orientation tool due to technical issues. $L^{*}$ and magnetic susceptibility signals reflecting cyclical relative contribution of biogenic carbonate are similar to bettercharacterized middle and late Pleistocene Lower Bengal Fan hemipelagic sediments deposited at 1-2 cm/ky (e.g., Weber et al., 2018), as opposed to higher accumulation rate turbiditic sediments that suggest this interval could record $\sim 0.8-1.6 \mathrm{My}$ of deposition. Paleomagnetic measurements conducted on board the R/V JOIDES Resolution with the superconducting rock magnetometer (SRM) revealed scattered directions that are likely the result of a weak natural remanent magnetization (NRM) and coring artifacts (see the Site U1451 chapter [France-Lanord et al., 2016c]). Shipboard calcareous nannofossil biostratigraphy identified the last occurrence of Discoaster pentaradiatus (2.39 Ma) between the core catchers of Cores $21 \mathrm{~F}$ and $22 \mathrm{H}$ and the last occurrence of Discoaster surculus (2.49 Ma) and Reticulofenestra pseudoumbilicus (3.70 Ma) between the core catchers of Cores $24 \mathrm{H}$ and $25 \mathrm{H}$. Shipboard planktonic foraminifer biostratigraphy identified the last occurrence of Dentoglobigerina altispira ( $3.47 \mathrm{Ma}$ ) between the core catchers of Cores $23 \mathrm{H}$ and $24 \mathrm{H}$ (see the Site U1451 chapter [France-Lanord et al., 2016c]; Gradstein et al., 2012). Although postexpedition research is in progress to refine the biostratigraphy, the locations of these biomarkers suggest that Cores $23 \mathrm{H}$ and $24 \mathrm{H}$ could contain magnetic reversals of the Gauss Chron and/or the Gauss/Matuyama boundary, which would provide strong tie points to the geomagnetic polarity timescale (GPTS) and constraints on the Pliocene/Pleistocene boundary, thus motivating a more detailed magnetostratigraphic study.

\section{Methods}

Shipboard paleomagnetic data were collected on the archive halves of sediment cores using the JOIDES Resolution 2G Enterprises long-core SRM and on two to four $7 \mathrm{~cm}^{3}$ paleomagnetic cubes per core using an AGICO JR-6 spinner magnetometer (a detailed discussion of shipboard methods and results can be found in the Expedition 354 methods and Site U1451 chapters [France-Lanord et al., 2016a, 2016c). An additional forty-nine $7 \mathrm{~cm}^{3}$ cubes were sampled from the working halves of Cores 354-U1451A-23H and $24 \mathrm{H}$ for further paleomagnetic analysis (Figure F2). Discrete subsamples have the advantage over shipboard archive-half section measurements in that discrete subsamples are taken from the center 
Figure F2. A, B. Locations of discrete samples measured on board and at the Oregon State University Paleomagnetic and Environmental Magnetic Research Laboratory, Cores $354-\mathrm{U} 1451 \mathrm{~A}-23 \mathrm{H}$ and $24 \mathrm{H}$. IW = interstitial water sample, $\mathrm{MBio}=$ microbiology sample, $\mathrm{PAL}=$ biostratigraphy sample.

A

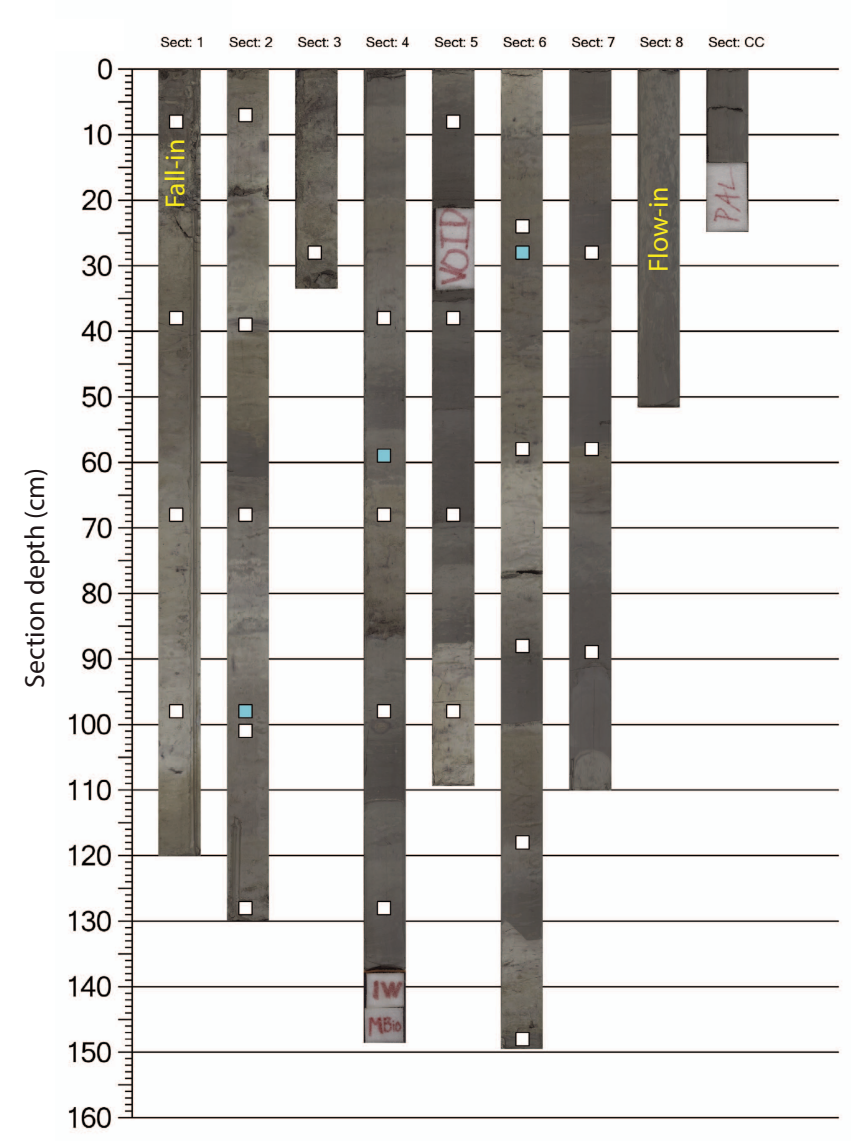

B

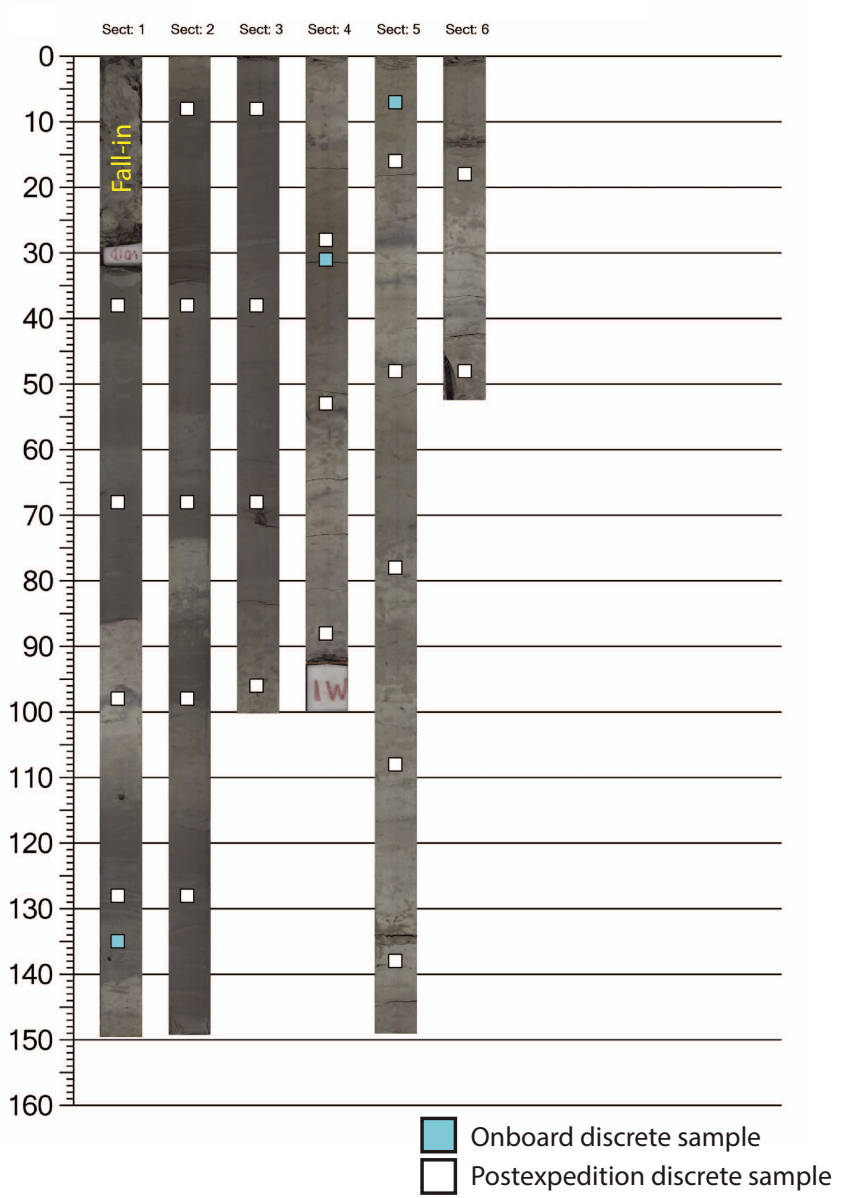

of the core and are therefore free from sediment deformation near the core edges (e.g., Acton et al., 2002). Discrete subsamples also are free from rust flakes, which are sometimes found between the sediment and core liner (Richter et al., 2007). The presence of rust flakes was observed visually and in high magnetic susceptibility and magnetic remanence in some sections cored during Expedition 354. Additionally, shore-based measurements can typically be done in a more controlled environment with enough time for detailed demagnetization work, allowing for better characterization of weakly magnetized materials.

The NRM and subsequent remanent magnetizations of the discrete samples were measured before and after peak alternating field (AF) demagnetization fields of $10-45 \mathrm{mT}$ in $2.5 \mathrm{mT}$ increments and $50-60 \mathrm{mT}$ in $5 \mathrm{mT}$ increments (19 measurements) at the Oregon State University Paleomagnetic and Environmental Magnetic Research Laboratory on a 2G Enterprises model 755-1.65UC SRM with in-line AF coils optimized for U-channel samples. Following NRM demagnetization, an anhysteretic remanent magnetization (ARM) was applied in a $100 \mathrm{mT}$ peak AF with a $0.05 \mathrm{mT}$ biasing field, measured, and demagnetized using the same peak AF as the NRM. As many as eight discrete samples spaced $20 \mathrm{~cm}$ apart were measured on a single tray. Measurements were made every $5 \mathrm{~cm}$ with a $10 \mathrm{~cm}$ leader and trailer, providing measurements before, af- ter, and between samples to monitor for flux jumps and drift using UPMAG MATLAB tools (Xuan and Channell, 2009). The AF demagnetization of the NRM was investigated to isolate a characteristic remanent magnetization (ChRM) using PuffinPlot (Lurcock and Wilson, 2012) and a principal component analysis (PCA) without anchoring to the origin (Kirschvink, 1980). ChRM directional precision was estimated using the maximum angular deviation (MAD) to the 95\% confidence interval conversion of Khokhlov and Hulot (2016).

Magnetic susceptibility $(k)$ of the discrete samples was measured three times at both 0.465 and $4.65 \mathrm{kHz}$ operating frequencies with a $5 \mathrm{~s}$ averaging time on a Bartington MS2b sensor and MS3 meter. To monitor for the presence of superparamagnetic grains, $k_{\mathrm{fd}}$ was calculated as $100 \times\left(k_{4.65 \mathrm{kHz}}-k_{0.465 \mathrm{kHz}}\right) / k_{0.465 \mathrm{kHz}}$. Because there was no significant difference between the two frequencies, indicating no significant concentration of superparamagnetic grains, magnetic susceptibility values presented in this paper are the lower frequency results; however, all magnetic data are available in U1451A_ST1_PALEOMAG.xlsx in PALEOMAG in Supplementary material. The anhysteretic susceptibility $\left(k_{\mathrm{ARM}}\right)$ was calculated by normalizing the ARM by the applied biasing field. The ratio of $k_{\mathrm{ARM}} / k$ is used to monitor for changes in magnetic grain size because $k_{\mathrm{ARM}}$ is more sensitive to finer magnetic grains than $k$ (e.g., Ba- 
nerjee et al., 1981). For comparison, whole-round $k$ measured on board was converted from instrument units to SI by multiplying by $7.0 \times 10^{-6}$ (after Thomas et al., 2003).

\section{Results}

Discrete sample NRM intensity values are often weak, ranging from $2.30 \times 10^{-4}$ to $2.45 \times 10^{-2} \mathrm{~A} / \mathrm{m}$ with a median of $8.32 \times 10^{-4}$ $\mathrm{A} / \mathrm{m}$ (Figure F3). ARM intensity values range from $1.02 \times 10^{-3}$ to $1.87 \times 10^{-2} \mathrm{~A} / \mathrm{m}$ with a median of $2.10 \times 10^{-3} \mathrm{~A} / \mathrm{m}$. We note that the maximum values for NRM and ARM intensity are from the same sample (354-U1451A-23H-1W, 7-9 cm; $121.58 \mathrm{~m} \mathrm{CSF-A),} \mathrm{which} \mathrm{is}$ only sample whose magnetization exceeds $1 \times 10^{-2} \mathrm{~A} / \mathrm{m}$ for either measurement. A strong vertical magnetic overprint, most noticeable before $15-20 \mathrm{mT}$ peak AF demagnetization, is pervasive across all samples and is described in the Site U1451 chapter (France-Lanord et al., 2016c) and in most ocean drilling paleomagnetic studies (e.g., Richter et al., 2007). Following removal or partial removal of the vertical overprint, samples display either fairly linear demagnetization behavior or noisy but consistent demagnetization behavior on a Zijderveld plot (Zijderveld, 1967) (Figure F4). The coercivity of the magnetic remanence carriers, tracked by AF demagnetization behavior and $k_{\mathrm{ARM}} / k$ values, are consistent with magnetite and/or other ferrimagnetic Fe-Ti oxides as the dominant magnetic mineralogy; however, more diagnostic rock magnetic experiments are needed to definitively identify the remanence carriers.

ChRMs were isolated using between 6 and 16 demagnetization steps ranging from 15 to $60 \mathrm{mT}$ (Figure F4; see U1451A_ST1_PALEOMAG.xlsx in PALEOMAG in Supplementary material). The majority of samples have ChRMs that are defined well enough to be suitable for magnetostratigraphic study; however, $27 \%$ of the samples have MAD values of $>15$, which are often considered poorly defined (McElhinny and McFadden, 1999). We note that the MAD values could be artificially decreased through anchoring to the origin in the calculation of the PCA and elongating the covariance structure (e.g., Heslop and Roberts, 2016) or "optimizing" the PCA (e.g., Walczak et al., 2017) without significantly changing the directions themselves. However, we choose to not use either of these approaches because even with these large MAD values the two cores have fairly stable declinations when compared to other declinations in the same core and artificially reducing the MAD values would not change the overall interpretation. Therefore, we choose to present all the data calculated with unanchored PCAs only but include one sigma uncertainty using the MAD to $95 \%$ confidence interval of Khokhlov and Hulot (2016), which considers the number of demagnetization steps used and whether the PCA was anchored or unanchored (Figure F3). One sigma uncertainty for inclination and declination was calculated from the $95 \%$ confidence interval as in Donadini et al. (2009).

Modern geocentric axial dipole (GAD)-predicted inclinations for Site U1451 at $8^{\circ} \mathrm{N}$ are $\pm 16^{\circ}$. Paleolatitudes of the northwardmoving Indian plate suggest no more than a couple of degrees latitudinal movement since the late Pliocene, meaning GAD-predicted inclinations for this time period would be no shallower than about $\pm 12^{\circ}$ (Klootwijk et al., 1992). Probability distribution functions (PDFs) indicate that although not significantly different, inclination values are slightly less for Core 354-U1451A-23H than Core $24 \mathrm{H}$ (Figure F5). Although the Core $24 \mathrm{H}$ mean inclination PDF is centered around the normal polarity GAD-predicted value with a slight skew to more positive inclinations, the Core $23 \mathrm{H}$ mean inclination
Figure F3. Discrete sample magnetic results, Cores 354-U1451A-23H and $24 \mathrm{H}$. All onboard data are from France-Lanord et al. (2016c) and are edited to remove core gaps, section edges, and fall-in or flow-in intervals. A. Shipboard $L^{*}$ measurements indicate high variance and anticorrelation with magnetic susceptibility ( $k$ ), suggesting similar lithology to late Pleistocene hemipelagic deposits that are better characterized on the Lower Bengal Fan (e.g., Weber et al., 2018). B. Ratio of anhysteretic susceptibility $\left(k_{\text {ARM }}\right)$ to $k$. Assuming that magnetite is the dominant mineralogy, higher $k_{\mathrm{ARM}} / k$ values reflect higher relative concentration of fine magnetic minerals. $C$. Discrete sample $k$ (open circles) compared with shipboard whole-round data (dark blue line). D. ARM before demagnetization (open circles) and after the $20 \mathrm{mT}$ AF step (solid circles). E. Discrete sample NRM before demagnetization (open circles) and after the $20 \mathrm{mT}$ step (solid circles) compared with shipboard NRM data measured on the archive halves before demagnetization (dark blue line) and after the $20 \mathrm{mT}$ step (light blue line). F. Discrete sample ChRM (black circles) with $1 \sigma$ uncertainty (red line) compared with shipboard inclination after the $20 \mathrm{mT}$ AF step (light blue line). Solid circles = onboard discrete sample ChRM inclination. G. Discrete sample ChRM declination (see $\mathrm{F}$ for details). Relative declination values are arbitrarily rotated for Cores $23 \mathrm{H}$ and $24 \mathrm{H}$ by $-60^{\circ}$ and $+120^{\circ}$, respectively, to better visualize the data. These declination values do not necessarily reflect actual polarity because the absolute orientations of the cores are not known.

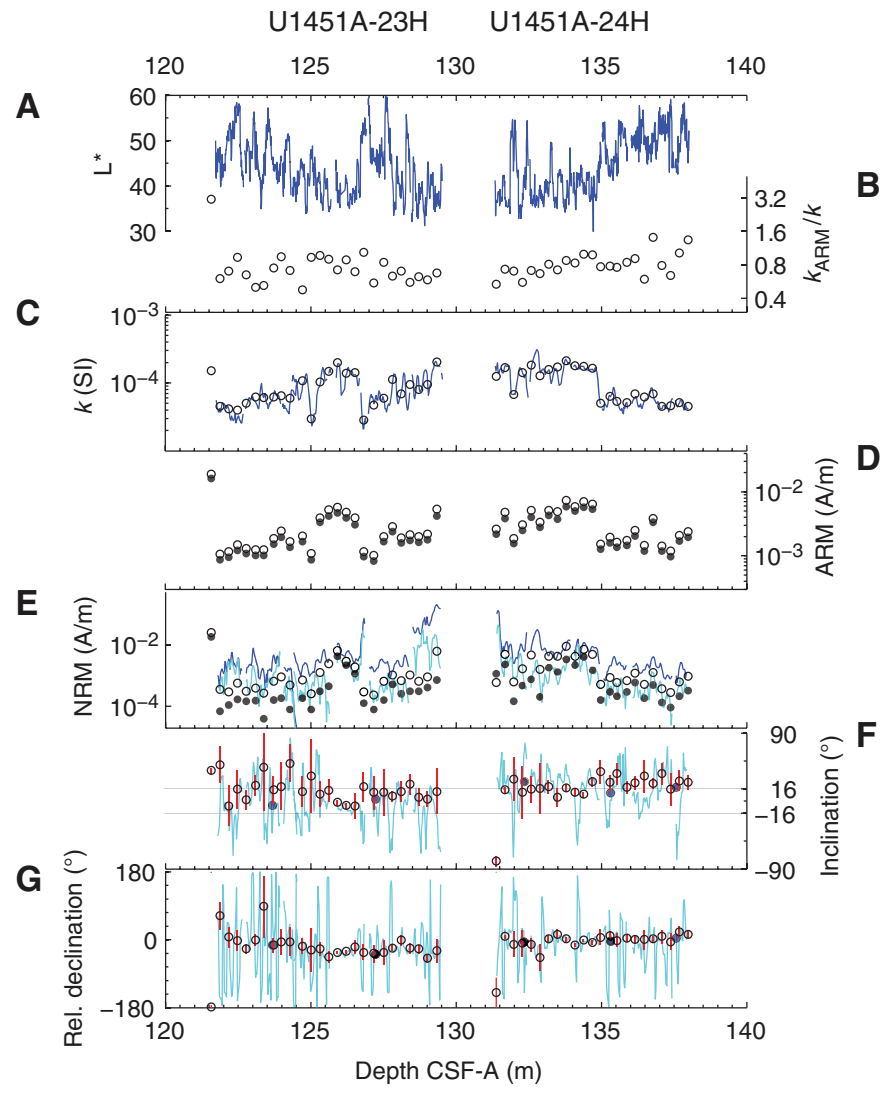

PDF is less well defined and centered between the reversed and normal polarity GAD-predicted value with a greater skew toward more positive inclinations. We note that when polarity is known in middle Pleistocene Expedition 354 sediments, shipboard archive-half and discrete measurements indicate that inclinations are always skewed to more positive values and are not a reliable predictor of normal or reversed polarity. This observation is true for single-AF step directions measured on the archive halves and when a ChRM was isolated with progressive demagnetization of discrete samples (see the Site U1451 chapter [France-Lanord et al., 2016c]). This 
Figure F4. Zijderveld plots (Zijderveld, 1967) illustrating AF demagnetization behavior of the NRM and subsequent remanent magnetizations. Every third sample is plotted to show examples of both well resolved (lower MAD values) and poorly resolved (higher MAD values) directions. Steps used to isolate the characteristic remanent magnetization in principal component analysis are indicated in darker colors. $I=$ inclination. $D=$ declination.
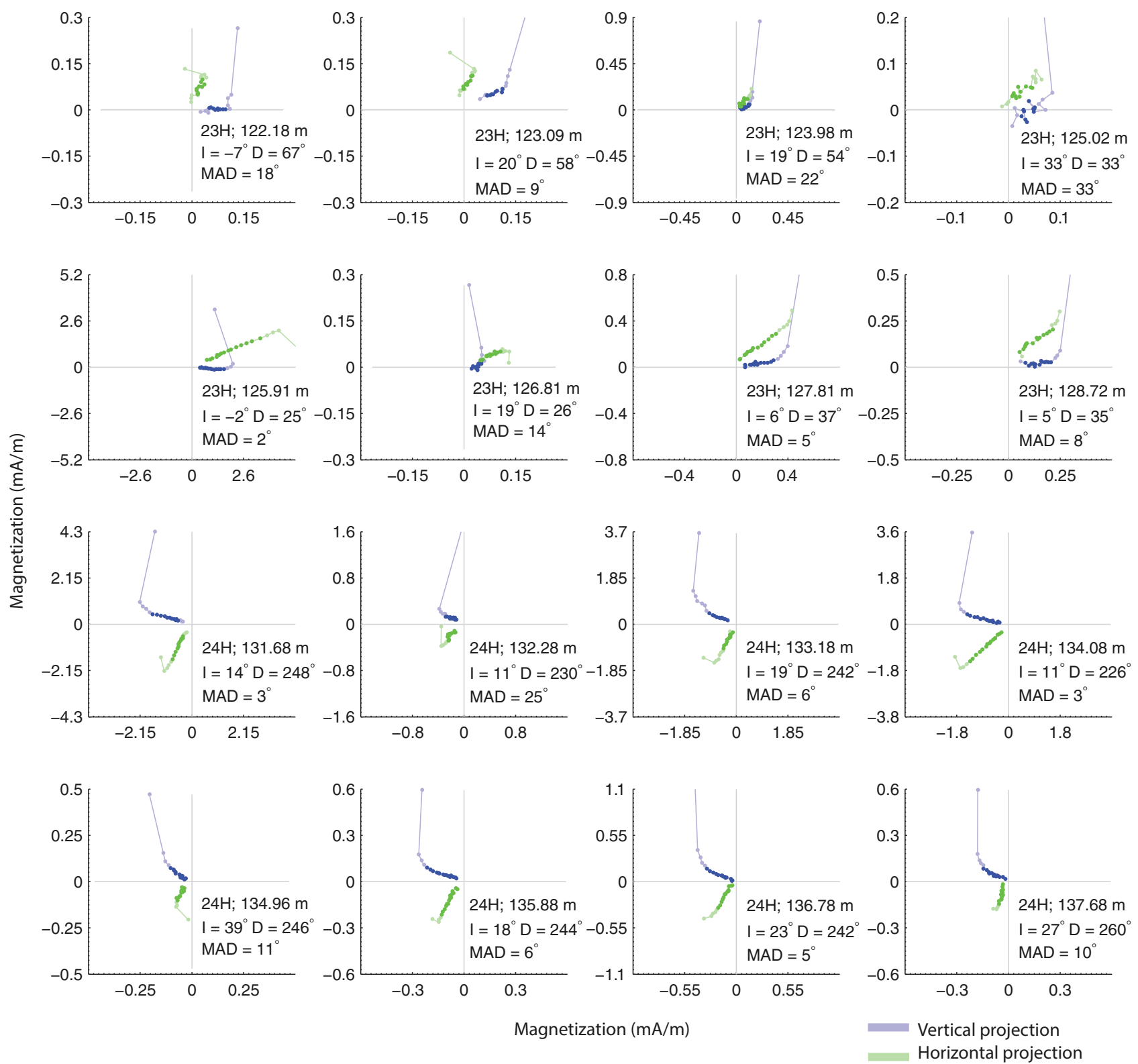

trend could reflect paleosecular variation, but it is more likely that the ChRM isolated by PCA is a mixture of at least two components with overlapping coercivities, which is suggested by slightly curved demagnetization behavior on some Zijderveld plots (Figure F4). Thus, the ChRM presented here is likely a mixture of the magnetization that approximates the paleogeomagnetic field acquired as a depositional or postdepositional remanent magnetization and either a persistent influence of the viscous isothermal remanent magnetization imparted during core recovery (e.g., Richter et al., 2007) or a viscous remanent magnetization from the Brunhes normal polarity chron overprinting past reversed magnetizations. Therefore, as was done on board with unoriented cores, magnetostratigraphy can only be based on declination within single cores where all sections are split along a common plane (i.e., a core either contains magnetic reversals or was deposited during a period of stable polarity).
Almost all declinations in both Cores 354-U1451A-23H and $24 \mathrm{H}$ suggest that each core was deposited in a period of stable polarity (Figure F3G). Anomalous declinations are present in the upper $40 \mathrm{~cm}$ of both cores and in one additional sample, 23H-2, 67-69 $\mathrm{cm}$ (123.38 m CSF-A). The upper $12 \mathrm{~cm}$ of Core $23 \mathrm{H}$ and upper 29 $\mathrm{cm}$ of Core $24 \mathrm{H}$ were described by the shipboard scientists as having "fall-in" (Figure F2) (see the Site U1451 chapter [France-Lanord et al., 2016c]). The one discrete sample taken from the fall-in at the top of Core $23 \mathrm{H}$ (7-9 cm core depth) has very high NRM intensity (the only sample that exceeds $10^{-2} \mathrm{~A} / \mathrm{m}$ ) and ARM intensity. The anomalous sample in Core $24 \mathrm{H}$ has an almost $-80^{\circ}$ inclination. Accordingly, we determine that samples from the uppermost $40 \mathrm{~cm}$ likely reflect coring artifacts and should not be used in magnetostratigraphic interpretation. The other anomalous sample at 67$69 \mathrm{~cm}$ in Section 23H-2 has the lowest NRM intensity after $20 \mathrm{mT}$ 
Figure F5. A, B. PDFs of ChRM directions (see text for discussion of estimating confidence intervals) for discrete samples (solid lines) and the mean of discrete samples (shaded areas), Cores $354-\mathrm{U} 1451 \mathrm{~A}-23 \mathrm{H}$ and $24 \mathrm{H}$. Declinations are arbitrarily rotated in each core for plotting purposes and do not necessarily reflect polarity. PDFs of samples from the upper $40 \mathrm{~cm}$ of each core are not plotted. Vertical gray bars = Pliocene and Pleistocene GAD-predicted direction range. Dashed lines $=$ predicted direction distribution for a normal polarity sample at $8^{\circ} \mathrm{N}$ from the TK03 paleosecular variation model (Tauxe and Kent, 2004).
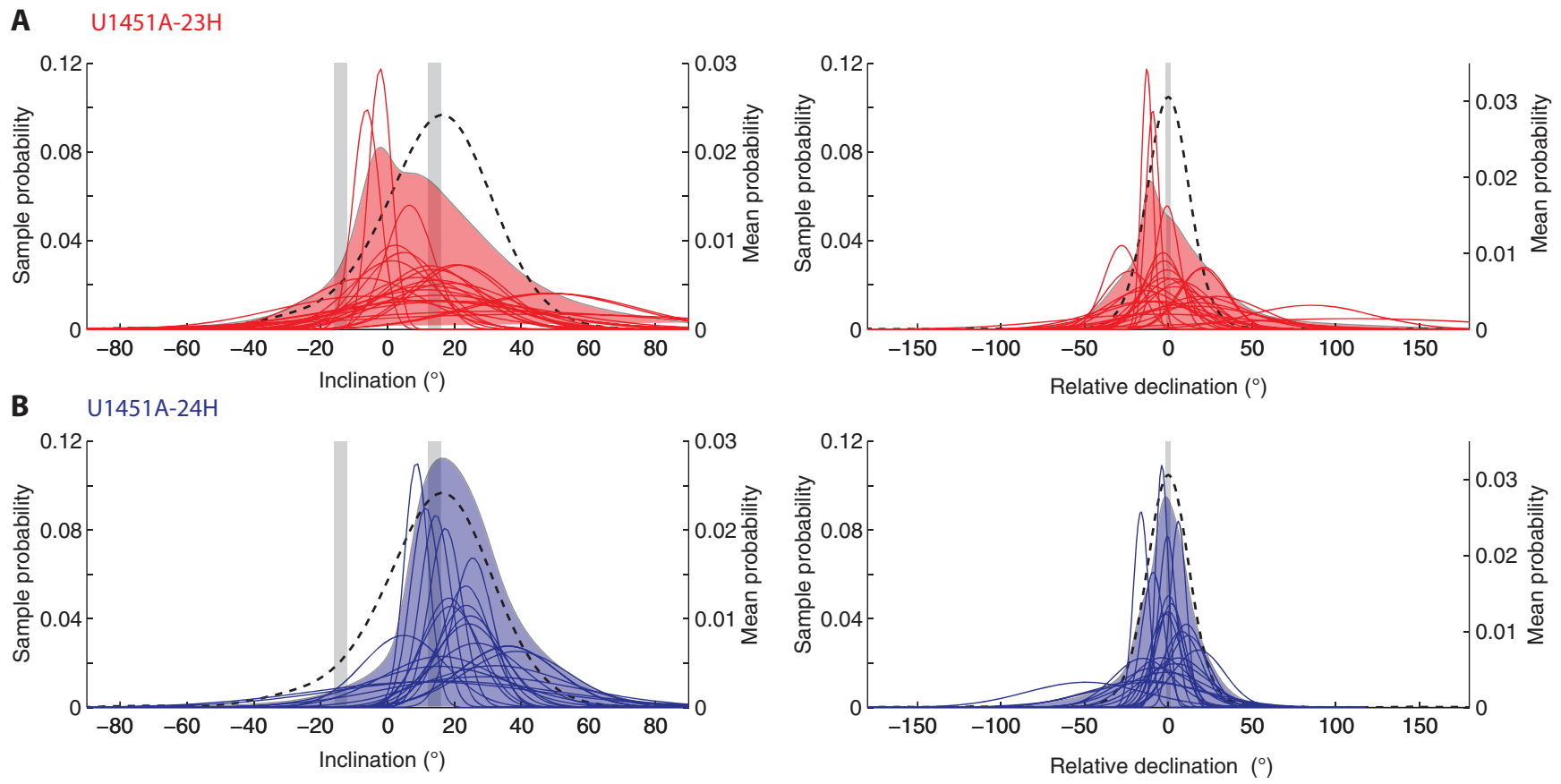

demagnetization $\left(3.04 \times 10^{-5} \mathrm{~A} / \mathrm{m}\right)$ and the highest MAD value $\left(39.7^{\circ}\right)$, which suggests that we cannot accurately resolve its ChRM.

Based on these data, sediments recovered in both Cores $23 \mathrm{H}$ and $24 \mathrm{H}$ were each deposited during times of stable geomagnetic polarity. Based on shipboard biostratigraphic data, it is likely that these sediments were deposited during either the early Matuyama Chron C2r (1.945-2.581 Ma; 0.636 My duration) or late Gauss Chron C2An.1n (2.581-3.032 Ma; 0.451 My duration) (Gradstein et al., 2012). Given hemipelagic calcareous clay sedimentation rates of $\sim 1-2 \mathrm{~cm} / \mathrm{ky}$ in the middle Pleistocene (see the Expedition 354 summary chapter [France-Lanord et al., 2016b]), we roughly expect Core 354-U1451A-23H (7.92 m of sediment excluding fall-in and flow-in) to have been deposited over 0.396-0.792 My and Core $24 \mathrm{H}$ (6.81 m of sediment excluding fall-in and voids) to have been deposited over $0.341-0.681 \mathrm{My}$, making it unlikely that both cores were deposited in exclusively Chron C2r or Subchron C2An.1n. This suggests the Gauss/Matuyama boundary $(2.581 \mathrm{Ma})$ is located between the base of Core 23H and top of Core 24H (129.54-131.33 m CSFA), which can be tested when postexpedition biostratigraphic studies are complete.

\section{Acknowledgments}

We are very grateful to the captain, crew, staff, and shipboard scientists that made Expedition 354 and subsequent research successful. All samples and data were provided by the International Ocean Discovery Program (IODP). We thank Yang (Wendy) Zhang for a thoughtful and constructive review of this data report. This work was made possible by support from a United States Science Support Program postexpedition award to B.T. Reilly. We also thank Leslie and Mark Workman and the Oregon ARCS Foundation for additional support to B.T. Reilly.

\section{References}

Acton, G.D., Okada, M., Clement, B.M., Lund, S.P., and Williams, T., 2002. Paleomagnetic overprints in ocean sediment cores and their relationship to shear deformation caused by piston coring. Journal of Geophysical Research: Solid Earth, 107(B4):2067-2081. https://doi.org/10.1029/2001JB000518

Banerjee, S.K., King, J., and Marvin, J., 1981. A rapid method for magnetic granulometry with applications to environmental studies. Geophysical Research Letters, 8(4):333-336. https://doi.org/10.1029/GL008i004p00333

Clemens, S.C., Kuhnt, W., LeVay, L.J., Anand, P., Ando, T., Bartol, M., Bolton, C.T., Ding, X., Gariboldi, K., Giosan, L., Hathorne, E.C., Huang, Y., Jaiswal, P., Kim, S., Kirkpatrick, J.B., Littler, K., Marino, G., Martinez, P., Naik, D., Peketi, A., Phillips, S.C., Robinson, M.M., Romero, O.E., Sagar, N., Taladay, K.B., Taylor, S.N., Thirumalai, K., Uramoto, G., Usui, Y., Wang, J., Yamamoto, M., and Zhou, L., 2016. Expedition 353 summary. In Clemens, S.C., Kuhnt, W., LeVay, L.J., and the Expedition 353 Scientists, Indian Monsoon Rainfall. Proceedings of the International Ocean Discovery Program, 353: College Station, TX (International Ocean Discovery Program). https://doi.org/10.14379/iodp.proc.353.101.2016

Donadini, F., Korte, M., and Constable, C.G., 2009. Geomagnetic field for 0-3 ka: 1 . New data sets for global modeling. Geochemistry, Geophysics, Geosystems, 10(6):Q06007. https://doi.org/10.1029/2008GC002295

France-Lanord, C., Spiess, V., Klaus, A., Adhikari, R.R., Adhikari, S.K., Bahk, J.-J., Baxter, A.T., Cruz, J.W., Das, S.K., Dekens, P., Duleba, W., Fox, L.R., Galy, A., Galy, V., Ge, J., Gleason, J.D., Gyawali, B.R., Huyghe, P., Jia, G., Lantzsch, H., Manoj, M.C., Martos Martin, Y., Meynadier, L., Najman, Y.M.R., Nakajima, A., Ponton, C., Reilly, B.T., Rogers, K.G., Savian, J.F., Schwenk, T., Selkin, P.A., Weber, M.E., Williams, T., and Yoshida, K., 2016a. Expedition 354 methods. In France-Lanord, C., Spiess, V., Klaus, A., Schwenk, T., and the Expedition 354 Scientists, Bengal Fan. Proceedings of the International Ocean Discovery Program, 354: College Station, TX (International Ocean Discovery Program).

https://doi.org/10.14379/iodp.proc.354.102.2016 
France-Lanord, C., Spiess, V., Klaus, A., Schwenk, T., Adhikari, R.R., Adhikari, S.K., Bahk, J.-J., Baxter, A.T., Cruz, J.W., Das, S.K., Dekens, P., Duleba, W., Fox, L.R., Galy, A., Galy, V., Ge, J., Gleason, J.D., Gyawali, B.R., Huyghe, P., Jia, G., Lantzsch, H., Manoj, M.C., Martos Martin, Y., Meynadier, L., Najman, Y.M.R., Nakajima, A., Ponton, C., Reilly, B.T., Rogers, K.G., Savian, J.F., Selkin, P.A., Weber, M.E., Williams, T., and Yoshida, K., 2016b. Expedition 354 summary. In France-Lanord, C., Spiess, V., Klaus, A., Schwenk, T., and the Expedition 354 Scientists, Bengal Fan. Proceedings of the International Ocean Discovery Program, 354: College Station, TX (International Ocean Discovery Program). https://doi.org/10.14379/iodp.proc.354.101.2015

France-Lanord, C., Spiess, V., Klaus, A., Adhikari, R.R., Adhikari, S.K., Bahk, J.-J., Baxter, A.T., Cruz, J.W., Das, S.K., Dekens, P., Duleba, W., Fox, L.R., Galy, A., Galy, V., Ge, J., Gleason, J.D., Gyawali, B.R., Huyghe, P., Jia, G., Lantzsch, H., Manoj, M.C., Martos Martin, Y., Meynadier, L., Najman, Y.M.R., Nakajima, A., Ponton, C., Reilly, B.T., Rogers, K.G., Savian, J.F., Schwenk, T., Selkin, P.A., Weber, M.E., Williams, T., and Yoshida, K., 2016c. Site U1451. In France-Lanord, C., Spiess, V., Klaus, A., Schwenk, T., and the Expedition 354 Scientists, Bengal Fan. Proceedings of the International Ocean Discovery Program, 354: College Station, TX (International Ocean Discovery Program).

https://doi.org/10.14379/iodp.proc.354.105.2016

Gradstein, F.M., Ogg, J.G., Schmitz, M.D., and Ogg, G.M. (Eds.), 2012. The Geological Time Scale 2012: Amsterdam (Elsevier).

Heslop, D., and Roberts, A.P., 2016. Analyzing paleomagnetic data: to anchor or not to anchor? Journal of Geophysical Research: Solid Earth, 121(11):7742-7753. https://doi.org/10.1002/2016JB013387

Khokhlov, A., and Hulot, G., 2016. Principal component analysis of palaeomagnetic directions: converting a maximum angular deviation (MAD) into an $\alpha 95$ angle. Geophysical Journal International, 204(1):274-291. https://doi.org/10.1093/gii/ggv451

Kirschvink, J.L., 1980. The least-squares line and plane and the analysis of palaeomagnetic data. Geophysical Journal of the Royal Astronomical Society, 62(3):699-718. https://doi.org/10.1111/j.1365-246X.1980.tb02601.x

Klootwijk, C.T., Gee, J.S., Peirce, J.W., Smith, G.M., and McFadden, P.L., 1992. An early India-Asia contact: paleomagnetic constraints from Ninetyeast Ridge, ODP Leg 121. Geology, 20(5):395-398. https://doi.org/10.1130/0091-7613(1992)020<0395:AEI$\mathrm{ACP}>2.3 . \mathrm{CO} ; 2$
Lurcock, P.C., and Wilson, G.S., 2012. PuffinPlot: a versatile, user-friendly program for paleomagnetic analysis. Geochemistry, Geophysics, Geosystems, 13(6):Q06Z45. https://doi.org/10.1029/2012GC004098

McElhinny, M.W., and McFadden, P.L., 1999. Paleomagnetism: Continents and Oceans: San Diego (Academic Press).

Richter, C., Acton, G., Endris, C., and Radsted, M., 2007. Technical Note 34: Handbook for Shipboard Paleomagnetists. Ocean Drilling Program. https://doi.org/10.2973/odp.tn.34.2007

Tauxe, L., and Kent, D.V., 2004. A simplified statistical model for the geomagnetic field and the detection of shallow bias in paleomagnetic inclinations: was the ancient magnetic field dipolar? In Channell, J.E.T., Kent, D.V., Lowrie, W., and Meert, J.G. (Eds.), Timescales of the Paleomagnetic Field. Geophysical Monograph, 145:101-115. https://doi.org/10.1029/145GM08

Thomas, R.G., Guyodo, Y., and Channell, J.E.T., 2003. U channel track for susceptibility measurements. Geochemistry, Geophysics, Geosystems, 4(6):1050. https://doi.org/10.1029/2002GC000454

Walczak, M.H., Stoner, J.S., Mix, A.C., Jaeger, J., Rosen, G.P., Channell, J.E.T., Heslop, D., and Xuan, C., 2017. A 17,000 yr paleomagnetic secular variation record from the southeast Alaskan margin: regional and global correlations. Earth and Planetary Science Letters, 473:177-189. https://doi.org/10.1016/j.epsl.2017.05.022

Weber, M.E., Lantzsch, H., Dekens, P., Das, S.K., Reilly, B.T., Martos, Y.M., Meyer-Jacob, C., et al., 2018. 200,000 years of monsoonal history recorded on the lower Bengal Fan-strong response to insolation forcing. Global and Planetary Change, 166:107-119.

https://doi.org/10.1016/j.gloplacha.2018.04.003

Xuan, C., and Channell, J.E.T., 2009. UPmag: MATLAB software for viewing and processing $\mathrm{U}$ channel or other pass-through paleomagnetic data. Geochemistry, Geophysics, Geosystems, 10(10):Q10Y07. https://doi.org/10.1029/2009GC002584

Zijderveld, J.D.A., 1967. AC demagnetization of rocks: analysis of results. In Collinson, D.W., Creer, K.M., and Runcorn, S.K. (Eds.), Developments in Solid Earth Geophysics (Volume 3): Methods in Palaeomagnetism: Amsterdam (Elsevier), 254-286. https://doi.org/10.1016/B978-1-4832-2894-5.50049-5 